\title{
REDUCTION OF ZERO SEQUENCE VOLTAGE USING MULTILEVEL INVERTER FED OPEN-END WINDING INDUCTION MOTOR DRIVE
}

\author{
Mahamkali RANJIT, Sara GOWTAMI, Bommasani GANESH BABU \\ Department of Electrical and Electronics Engineering, VNR Vignana Jyothi Institute of Engineering and Technology, Hyderabad, \\ Telangana, India, E-mail: ranjit221@gmail.com, gowthami.s699@gmail.com, ganeshbabu_b@vnrvjiet.in
}

\begin{abstract}
Modern inverters have been employed to achieve high dynamic operation in the context of variable speed drives. But due to high $d v / d t$ introduces Zero Sequence Voltage (ZSV) results in adverse effects like bearing currents and electromagnetic interference. In this proposed work, the techniques to overcome the drawbacks due to conventional inverter and multilevel inverter have been presented i.e, by using multilevel inverter fed open end winding. In this paper the performance characteristics of Induction motor with different PWM techniques like sinusoidal PWM (SPWM), third harmonic injection PWM(THIPWM) have been analyzed and the harmonic analysis has been carried out using MATLAB/SIMULINK environment and to validate the proposed work, several simulation results for different modulation index are listed out.
\end{abstract}

Keywords: Zero Sequence Voltage (ZSV), bearing currents, open end winding induction motor drive, SPWM, THIPWM, modulation index

\section{INTRODUCTION}

An inverter is a power electronic device used to convert constant DC power to adjustable voltage adjustable frequency $\mathrm{AC}$ power drives. To raise the blocking capacity in conventional two-level inverter the switching devices are connected in series. The simultaneous switching of series connected fast devices generates voltage with a high $\mathrm{dv} / \mathrm{dt}$ at the output terminal of the inverter [1-2]. Due to this the conventional inverter are known to generate "Zero Sequence voltage" or "common mode voltage" because of parasitic stray capacitors inevitably exists inside the AC motor as shown in the Fig. 1. They also result in leakage currents which act as sources of conductive electromagnetic interference in the drive system and also lead to permanent failure in motor bearings.

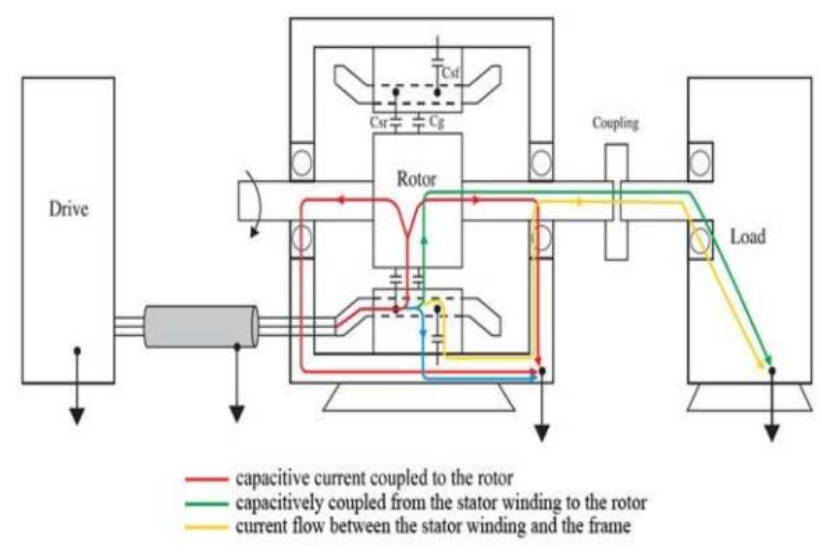

Fig. 1 Paths of bearing currents inside the motor

In order to eliminate the zero sequence voltage in the context of variable speed motor drives different techniques have been employed and are classified as [3][4][5]:

A) Using isolation transformer, zero sequence impedance, filters,
B) using multilevel inverters, using dual bridge inverter fed induction motor drive(open end winding) or

C) using different modulation techniques like sinusoidal PWM (SPWM), third harmonic injection PWM (THIPWM) and Space vector PWM (SVPWM) techniques [7].

The methods proposed in [A] above increases the system cost as it employs some extra hardware circuitry and complexity in control.

Multilevel inverters are also employed and are extensively used in high power, high-voltage variable speed drive systems. As the number of voltage levels increases, the harmonic content of the output voltage waveform decreases due to which low total harmonic distortion (THD) with high efficiency and power factor is obtained [4]. But the complexity, number switches increases as the number of level increases in order to overcome this, this paper is mainly focused on by using proposed inverter fed open end winding (3,4,5,6 level) operated with different control strategies like SPWM, Third harmonic injection control techniques [8][9][10].

The advantages of dual-inverter fed induction motor drive topologies are that the voltage amplitude required to produce air-gap flux in the machine is divided among the two inverters. Therefore, the device ratings as well as $\mathrm{dv} / \mathrm{dt}$ stress are reduced, which is very important for high power applications and reduces the zero sequence voltage up to great extent and also reduces bearing currents.

\section{MULTILEVEL INVERTERS FED OPEN END WINDING INDUCTION MOTOR DRIVE}

\section{3\&4-level inverter}

In this configuration Induction Motor is fed by two inverters from either side which are operated by isolated power supply. A schematic diagram of dual inverter fed Induction Motor drive is shown in the Fig. 2. 


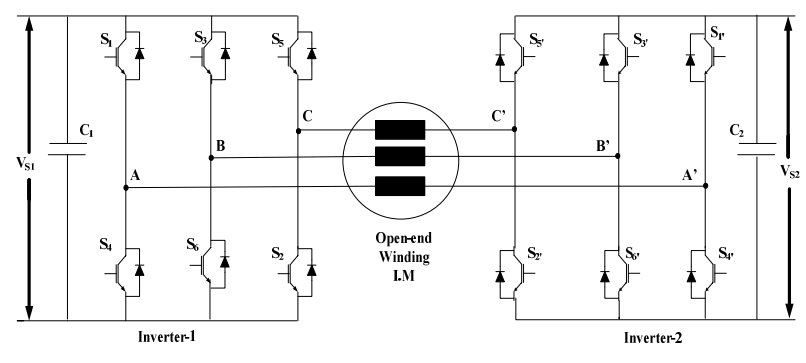

Fig. 2 Dual inverter fed open end winding IM drive

From the Fig. 2, INV1 and INV2 are conventional two level inverters. Here $\mathrm{S}_{1}, \mathrm{~S}_{2}, \mathrm{~S}_{3}, \mathrm{~S}_{4}, \mathrm{~S}_{5}, \mathrm{~S}_{6}$ are the switches of inverter-1 and $\mathrm{S}_{1}, \mathrm{~S}_{2}, \mathrm{~S}_{3}, \mathrm{~S}_{4}, \mathrm{~S}_{5}, \mathrm{~S}_{6}$, are the switches of inverter-2. These two inverters are supplied with the isolated DC -link voltages, these isolated DC-link voltages are equal (i.e. $\mathrm{V}_{\mathrm{S} 1}=\mathrm{V}_{\mathrm{DC}} / 2 \& \mathrm{~V}_{\mathrm{S} 2}=\mathrm{V}_{\mathrm{DC}} / 2$ ) then the configuration resembles to that of a three level inverter. If the inverters are supplied with the isolated DC-link voltages (i.e. $\mathrm{V}_{\mathrm{S} 1}=2 \mathrm{~V}_{\mathrm{DC}} / 3 \quad \& \quad \mathrm{~V}_{\mathrm{S} 2}=\mathrm{V}_{\mathrm{DC}} / 3$ ) then the configuration resembles to that of a four level inverter.

For the given input of $\mathrm{V}_{\mathrm{DC}} / 2$, these two inverters can attain two levels namely $+\mathrm{V}_{\mathrm{DC}} / 4,-\mathrm{V}_{\mathrm{DC}} / 4$ for a three level inverter and is similar for four level inverter. In this $1 \& 0$ represents on and off states of switches of inverter-1, 1' \& 0 ' represents on and off states of switches of inverter-2.

The phase voltage for three level inverter can attain three levels namely namely $+\mathrm{V}_{\mathrm{DC}} / 2$ (+state), 0 and $-\mathrm{V}_{\mathrm{DC}} / 2$ (- state). For four level inverter the voltage levels in four level are $+\mathrm{V}_{\mathrm{DC}} / 2(+$ state $),+\mathrm{V}_{\mathrm{DC}} / 6(+$ state $),-\mathrm{V}_{\mathrm{DC}} / 2$ (-state) and $-\mathrm{V}_{\mathrm{DC}} / 2$ (- state).

$\mathrm{V}_{\mathrm{A} 0}, \mathrm{~V}_{\mathrm{B} 0}, \mathrm{~V}_{\mathrm{C} 0}$ are the pole voltages of inverter-1 and

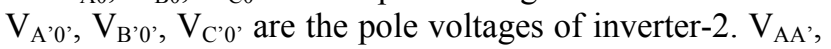
$\mathrm{V}_{\mathrm{BB}}, \mathrm{V}_{\mathrm{CC}}$, are the voltages across the phase winding of Induction Motor. Here the sum of all these phase voltages is not equal to zero, which results as zero sequence component in motor due to this the bearing currents will flow inside the motor.

$\mathrm{V}_{\mathrm{AA}^{\prime}}=\mathrm{V}_{\mathrm{A} 0}-\mathrm{V}_{\mathrm{A}^{\prime} 0^{\prime}}$

$\mathrm{V}_{\mathrm{BB}^{\prime}}=\mathrm{V}_{\mathrm{B} 0}-\mathrm{V}_{\mathrm{B}^{\prime} 0^{\prime}}$

$\mathrm{V}_{\mathrm{CC}^{\prime}}=\mathrm{V}_{\mathrm{C} 0}-\mathrm{V}_{\mathrm{C}^{\prime} 0^{\prime}}$

where $\mathrm{V}_{\mathrm{A} 0}, \mathrm{~V}_{\mathrm{B} 0}, \mathrm{~V}_{\mathrm{C} 0}$ are the pole voltages of inverter- 1

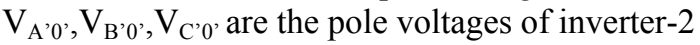
$\& \mathrm{~V}_{\mathrm{AA}}, \mathrm{V}_{\mathrm{BB}}, \mathrm{V}_{\mathrm{CC}}$, are the Phase voltages of the inverter

The Zero Sequence voltage or common mode voltage is given by

$\mathrm{V}_{\mathrm{ZS}}$ or $\mathrm{CMV}=\frac{\mathrm{V}_{\mathrm{AA}^{\prime}}+\mathrm{V}_{\mathrm{BB}^{\prime}}+\mathrm{V}_{\mathrm{CC}^{\prime}}}{3}$

The line voltages is obtained

$$
\begin{aligned}
& \mathrm{V}_{\mathrm{AN}}=\mathrm{V}_{\mathrm{AA}^{\prime}}-\mathrm{V}_{\mathrm{ZS}} \\
& \mathrm{V}_{\mathrm{BN}}=\mathrm{V}_{\mathrm{BB}^{\prime}}-\mathrm{V}_{\mathrm{ZS}} \\
& \mathrm{V}_{\mathrm{CN}}=\mathrm{V}_{\mathrm{CC}^{\prime}}-\mathrm{V}_{\mathrm{ZS}}
\end{aligned}
$$

\section{Diode Clamped Multilevel Inverter (DCMLI)}

The most commonly used topology is diode clamped inverter, in which the diode is used to clamp the dc bus voltage. The diode clamped multilevel inverter uses capacitors connected in series to divide up the dc bus voltage into a set of voltage levels. The topology of diodeclamped (neutral-point clamped) three-level inverter is shown in the below Fig. 3. The circuit has 12 power switching devices and 6 clamped diodes with two pairs of switches and two diodes on each leg. Two capacitors, C1 and $\mathrm{C} 2$ are connected in series in such a way that the bus voltage is divided into three-level. The midpoint of the two capacitors can be defined as the neutral point " $O$ " as a result the switch voltage is limited to half the level of the dc-bus voltage $\mathrm{V}_{\mathrm{DC}} / 2$. Thus, the voltage stress of switching device is greatly reduced. The output voltage $\mathrm{V}_{\mathrm{AO}}$ i.e. pole voltage has three different states: $+\mathrm{V}_{\mathrm{DC}} / 2,0$, $-\mathrm{V}_{\mathrm{DC}} / 2$. Here phase $\mathrm{A}$ is taken as an example. For voltage level ' $+\mathrm{V}_{\mathrm{DC}} / 2$ ', $\mathrm{S}_{1}$ and $\mathrm{S}_{2}$ switches are turned on; for ' 0 ' voltage level, the switches $S_{2}$ and $S_{1}$ ' are turned on; and for voltage level ' $-\mathrm{V}_{\mathrm{DC}} / 2$ ', $\mathrm{S}_{1}$ ' and $\mathrm{S}_{2}$ ' switches are turned on. The switches $\mathrm{S}_{1}$ and $\mathrm{S}_{1}{ }^{\prime}, \mathrm{S}_{2}$ and $\mathrm{S}_{2}$ ' are complementary.

\begin{tabular}{|l|l|l|l|l|}
\hline $\begin{array}{c}\text { Pole Voltage } \\
\left(\mathrm{V}_{\mathrm{A}} \mathrm{o}\right)\end{array}$ & \multicolumn{1}{|c|}{$\mathrm{S}_{1}$} & \multicolumn{1}{|c|}{$\mathrm{S}_{2}$} & \multicolumn{1}{|c|}{$\mathrm{S}_{1}{ }^{\prime}$} & \multicolumn{1}{c|}{$\mathrm{S}_{2}$} \\
\hline $\mathrm{V}_{\mathrm{DC}} / 2$ & ON & ON & OFF & OFF \\
\hline 0 & OFF & ON & ON & OFF \\
\hline$-\mathrm{V}_{\mathrm{DC}} / 2$ & OFF & OFF & ON & ON \\
\hline
\end{tabular}

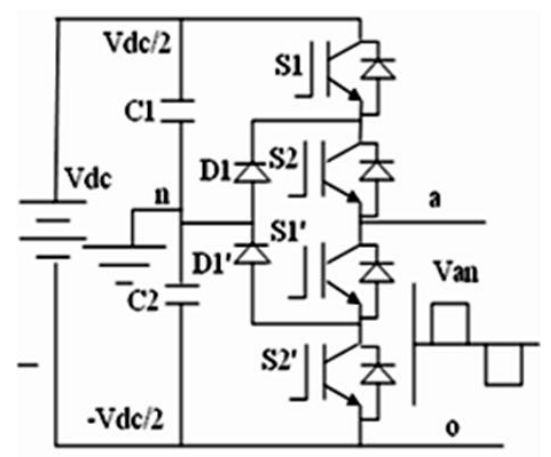

Fig. 3 Schematic of one leg of diode clamped inverter

\section{Configuration-I}

\section{5\&6-level inverter}

In this configuration Induction Motor is fed by two inverters from either side which are operated by isolated power supply, Where INV1 is a 3-level diode clamped multilevel inverter and INV2 is a conventional two level inverter. A schematic diagram of proposed inverter fed open end winding Induction Motor drive is shown in the Fig. 4. Here, $S_{1}-S_{12}$ are the switches of inverter-1 and $S_{1}$,$\mathrm{S}_{6}$, are the switches of inverter-2. These two inverters are supplied with half of DC-link voltage (i.e. Vs1 = Vs2= $\mathrm{V}_{\mathrm{DC}} / 2$ ) then the configuration resembles to five level inverter. The phase winding can attain five levels namely $+\mathrm{V}_{\mathrm{DC}} / 2(+$ state $),+\mathrm{V}_{\mathrm{DC}} / 4(+$ state $), 0,-\mathrm{V}_{\mathrm{DC}} / 2(-$ state $)$ and $\mathrm{V}_{\mathrm{DC}} / 4$ (-state). 


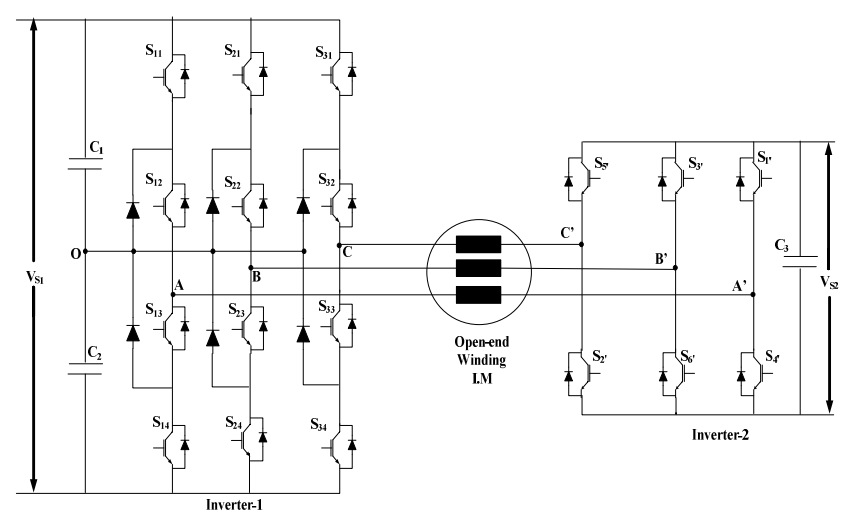

Fig. 4 Schematic of inverter fed open end winding I.M drive

If the inverters are supplied with isolated DC -link voltage (i.e. $\mathrm{V}_{\mathrm{S} 1}=2 \mathrm{~V}_{\mathrm{DC}} / 3 \quad \& \quad \mathrm{~V}_{\mathrm{S} 2}=\mathrm{V}_{\mathrm{DC}} / 6$ ) then the configuration resembles to that of a six level inverter whose working principle is similar to five level inverter. The Zero Sequence voltage or common mode voltage is given by the equation (4). The line voltages is obtained from the equations (5)-(7).

\section{Configuration-II}

\section{5\&6-level inverter}

A schematic diagram of inverter fed open end winding Induction Motor drive is shown in the Fig. 5 Where INV$\mathrm{X}$ is a 3-level inverter and INV-Y is a conventional two level inverter. The three level inverter (i.e. INV-X) is comprised of two, two level inverters (i.e. INV-1 \&INV2) connected in cascaded so that it resembles to that of a three level inverter.

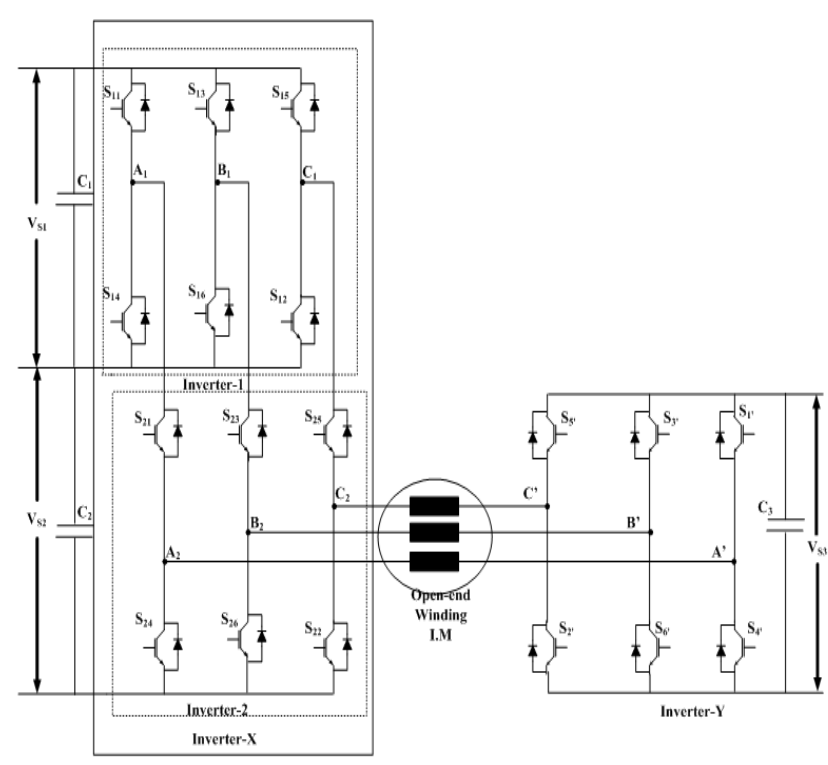

Fig. 5 Schematic of inverter fed open end winding I.M drive

Here, $S_{11}-S_{16}$ and $S_{21}-S_{26}$ are the switches of inverter-X and $S_{1},-S_{6}$, are the switches of inverter-Y. These two inverters are supplied with the asymmetrical DC -link voltages, where DC-link voltage of inverter-1 and inverter- $Y$ is $V_{D C} / 4$ each and the DC-link voltage of inverter-2 is $V_{D C} / 2$. This configuration resembles to that of a five level inverter. For the given input of $\mathrm{V}_{\mathrm{DC}} / 4$, inverter- $Y$ attains two levels namely $+\mathrm{V}_{\mathrm{DC}} / 8$ and $-\mathrm{V}_{\mathrm{DC}} / 8$. Inverter-X can attain three levels depending on the switching state. When the switches $\mathrm{S}_{11}$ and $\mathrm{S}_{24}$ is turned $\mathrm{ON}$ the pole voltage obtained is $-\mathrm{V}_{\mathrm{DC}} / 2, \mathrm{~S}_{14}$ and $\mathrm{S}_{21}$ is $\mathrm{ON}$ the pole voltage attains $\mathrm{V}_{\mathrm{DC}} / 4$ and $\mathrm{S}_{21}$ and $\mathrm{S}_{24}$ is OFF the pole voltage attains zero (' 0 ').

$\mathrm{V}_{\mathrm{A} 20}, \mathrm{~V}_{\mathrm{B} 20}, \mathrm{~V}_{\mathrm{C} 20}$ are the pole voltages of inverter-1 and $\mathrm{V}_{\mathrm{A}^{\prime} 0^{\prime}}, \mathrm{V}_{\mathrm{B}^{\prime} 0^{\prime}}, \mathrm{V}_{\mathrm{C}^{\prime} 0^{\prime}}$ are the pole voltages of inverter-2. $\mathrm{V}_{\mathrm{AA}}$, $\mathrm{V}_{\mathrm{BB}}, \mathrm{V}_{\mathrm{CC}}$ ' is the voltage across the phase winding of induction motor it can be obtained by the difference between the pole voltages, which is given by the equations (1)-(3) and the phase winding can attain five levels.

The Zero Sequence voltage or common mode voltage is given by the equation (4).

The line voltages is obtained from the equations (5)(7).

For a six level inverter whose working is same five level it is supplied with the asymmetrical DC-link voltages, where DC-link voltage of inverter-1 and inverter-2 is $2 \mathrm{~V}_{\mathrm{DC}} / 6$ each and the DC-link voltage of inverter- $\mathrm{Y}$ is $\mathrm{V}_{\mathrm{DC}} / 6$.

\section{MODULATING TECHNIQUES}

In order to have efficient and better performance of inverter different modulation techniques have been proposed. Multilevel inversion is a power conversion strategy in which the output voltage is obtained in steps thus bringing the output closer to a sine wave and reduces the Total Harmonic Distortion. In Pulse Width Modulation (PWM) for a fixed DC input we get a controlled AC output by adjusting turn on and turn off of device. In this method, it mitigates lower order harmonics. But, more pulses mean more switching losses [7].

\section{Sinusoidal PWM}

In this scheme, three sinusoidal reference waves each shifted by $120^{\circ}$ are used. A triangular carrier wave is compared with the reference signal corresponding to a phase to generate the gating signals for that phase. At every instant sinusoidal signal at desired frequency is compared with each carrier signal at high frequency. In this comparison if modulating signal is greater than triangular carrier signal, then signal is given to appropriate semi-conductor switch in respective legs. The reference voltages for a three-phase topology for balanced threephase system are given by.

$\mathrm{V}_{\text {Aref }}(\mathrm{t})=\mathrm{V}_{\mathrm{m}} \sin (\omega \mathrm{t})$

$\mathrm{V}_{\text {Bref }}(\mathrm{t})=\mathrm{V}_{\mathrm{m}} \sin (\omega \mathrm{t}-2 \pi / 3)$

$\mathrm{V}_{\text {Cref }}(\mathrm{t})=\mathrm{V}_{\mathrm{m}} \sin (\omega \mathrm{t}-4 \pi / 3)$

Modulation Index $=\underline{\text { Amplitude of Reference Signal( }(\mathrm{Am})}$ Amplitude of carrier Signal (Ac)

In Sinusoidal PWM technique de bus utilization is poor. To achieve more DC bus utilization to improve the output voltage profile we will go for third harmonic injection PWM and Space Vector PWM techniques. 


\section{Third Harmonic Injection PWM}

The sinusoidal PWM is unable to fully utilize the DC bus supply voltage and THD is also higher. So, the third harmonic injection pulse width modulation (THIPWM) technique was developed to increase the inverter performance. In this technique, a third harmonic component is superimposed on the fundamental which is given by the following equation

$\mathrm{y}=\frac{2}{\sqrt{3}}(\sin \omega \mathrm{t}+\mathrm{K} \sin 3 \omega \mathrm{t})$

Here, $k=1 / 6$ i.e. Injecting one sixth of the third harmonic component to the fundamental component or $\mathrm{K}=1 / 4$ i.e. Injecting one fourth of the third harmonic component to the fundamental component.

\section{SIMULATION RESULTS}

\section{A) For Diode Clamped multilevel inverter (three level)} fed I.M drive with SPWM control

A 3-level multilevel inverter (i.e. DCMLI) fed induction motor drive is modeled and is simulated by employing Sinusoidal pulse width modulation (SPWM) control technique with Modulation index $=1$ (over modulation) and the reference and carrier wave comparison, output phase voltage, line voltage and ZSV of the inverter are shown in Fig. 6.
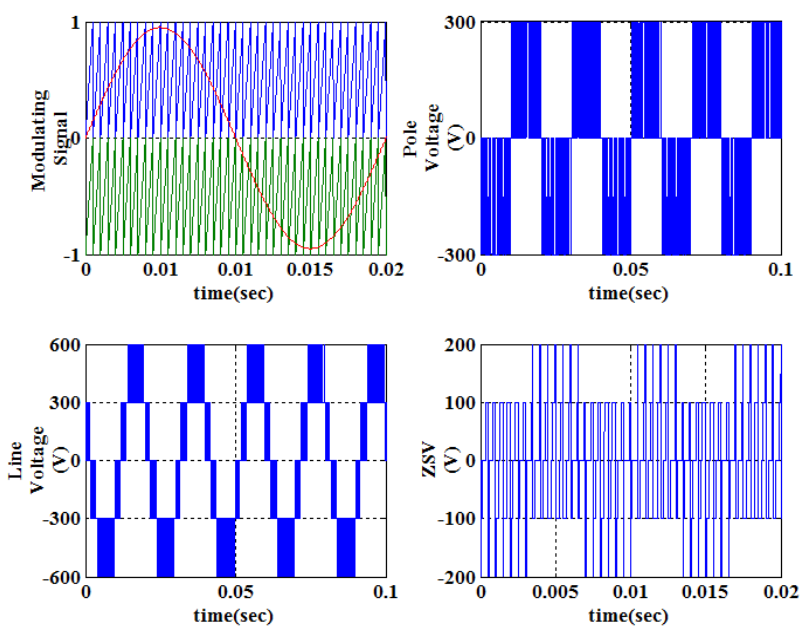

Fig. 6 Modulating signal, Pole voltage, Line voltage, ZSV for 3level inverter Using SPWM

The performance characteristics of Induction motor drive with SPWM controlled 3-Level Inverter (DCMLI) i.e. Stator currents, Torque, Speed shown in the fig. The motor achieves steady state at $0.15 \mathrm{sec}$ and load is applied from 0.5 to $0.8 \mathrm{sec}$ and then reaches its steady state as shown in Fig. 7.
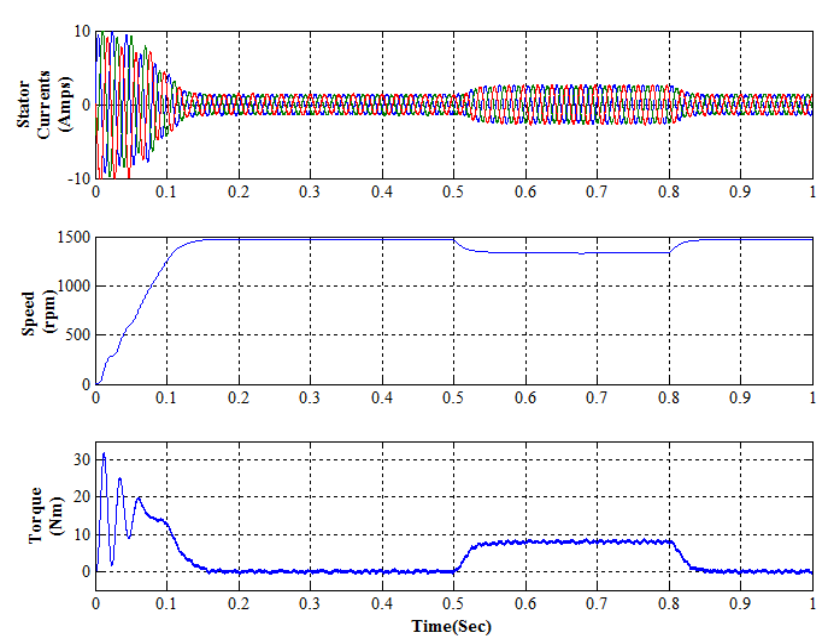

Fig. 7 Performance characteristics of IM drive with 3-level inverter Under load Condition

\section{For 3-level multilevel inverter fed I.M drive using SPWM}

3-level multilevel inverter fed I.M drive is modeled and is simulated by employing Sinusoidal pulse width modulation (SPWM) control technique with Modulation index $=1$ (over modulation) and the reference and carrier wave comparison, pole voltage, output phase voltage, line voltage and ZSV for proposed 3 level inverter are shown in Fig. 8.
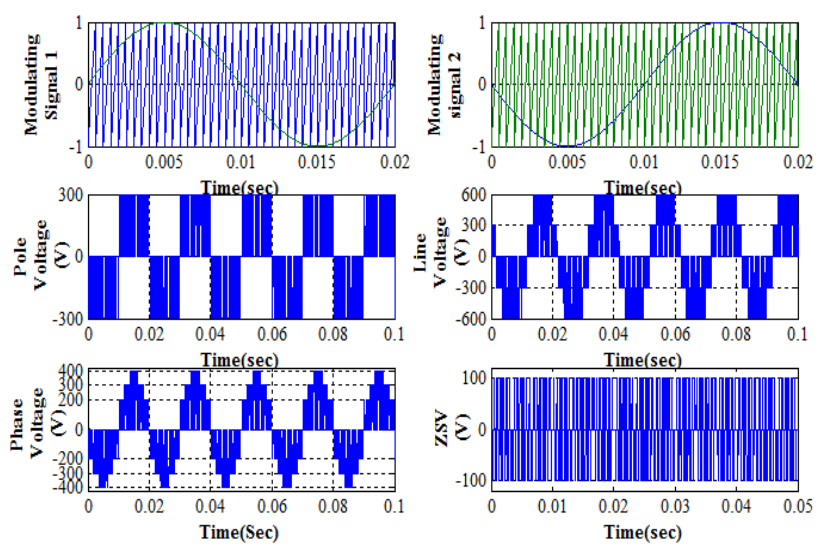

Fig. 8 Modulating signal, Pole voltage, Line voltage, phase voltage, ZSV for proposed 3-level inverter using SPWM

\section{For 4-level multilevel inverter fed I.M drive using SPWM}

4-level multilevel inverter fed I.M drive is modeled and is simulated by employing Sinusoidal pulse width modulation (SPWM) control technique with Modulation index $=1$ (over modulation) and the reference and carrier wave comparison, pole voltage, output phase voltage, line voltage and ZSV for proposed 4 level inverter are shown in Fig. 9. 

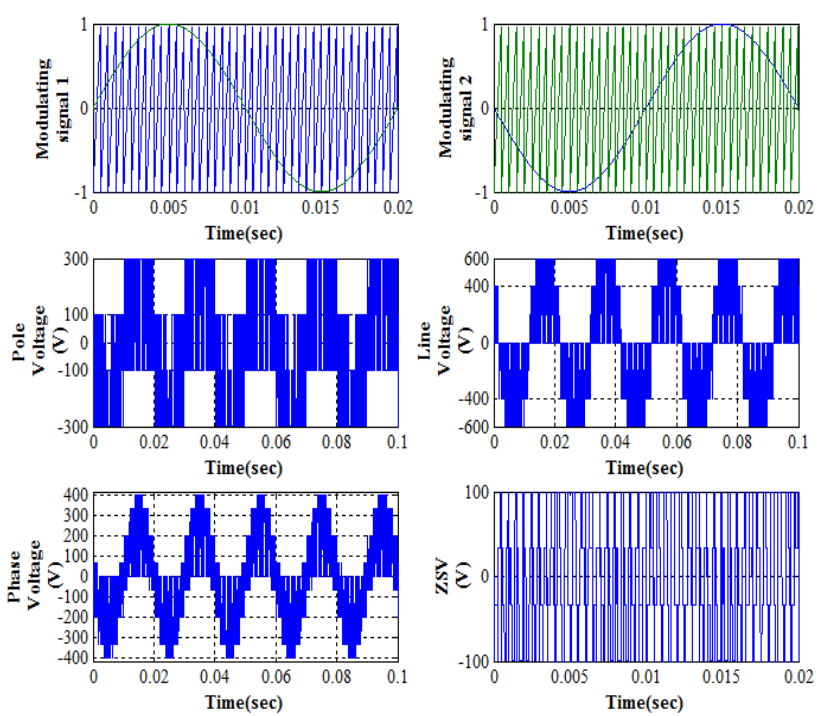

Fig. 9 Modulating signal, Pole voltage, Line voltage, phase voltage, ZSV for proposed 4-level inverter using SPWM

\section{Configuration-I}

\section{For 5-level multilevel inverter fed I.M drive using} SPWM

5-level multilevel inverter fed I.M drive is modeled and is simulated by employing Sinusoidal pulse width modulation (SPWM) control technique with Modulation index $=1$ (over modulation) and the reference and carrier wave comparison, pole voltage, output phase voltage, line voltage and ZSV for proposed 5 level inverter are shown in Fig. 10.
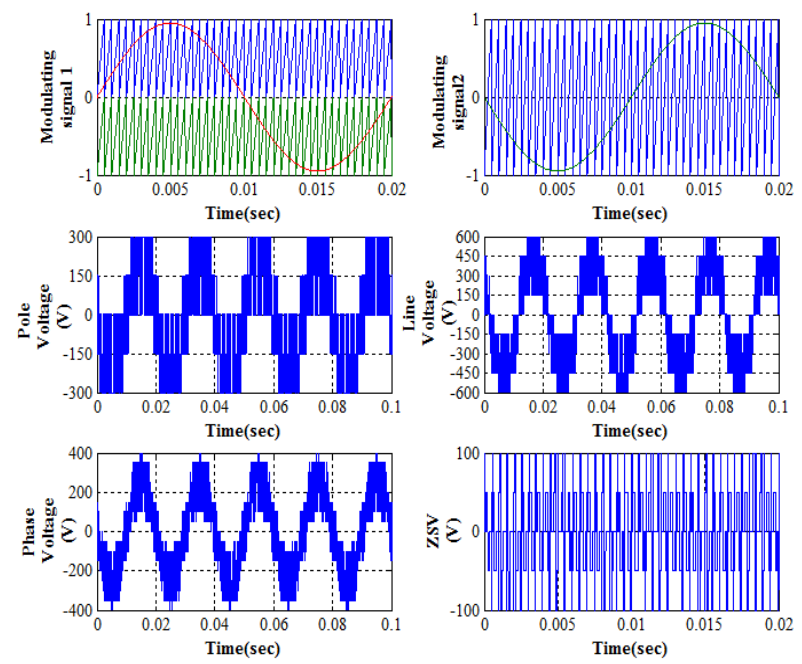

Fig. 10 Modulating signal, Pole voltage, Line voltage, phase voltage, ZSV for proposed 5-level inverter using SPWM

\section{For 6-level multilevel inverter fed I.M drive using SPWM}

6-level multilevel inverter fed I.M drive is modeled and is simulated by employing Sinusoidal pulse width modulation (SPWM) control technique with Modulation index $=1$ (over modulation) and the reference and carrier wave comparison, pole voltage, output phase voltage, line voltage and ZSV for proposed 6 level inverter are shown in Fig. 11.
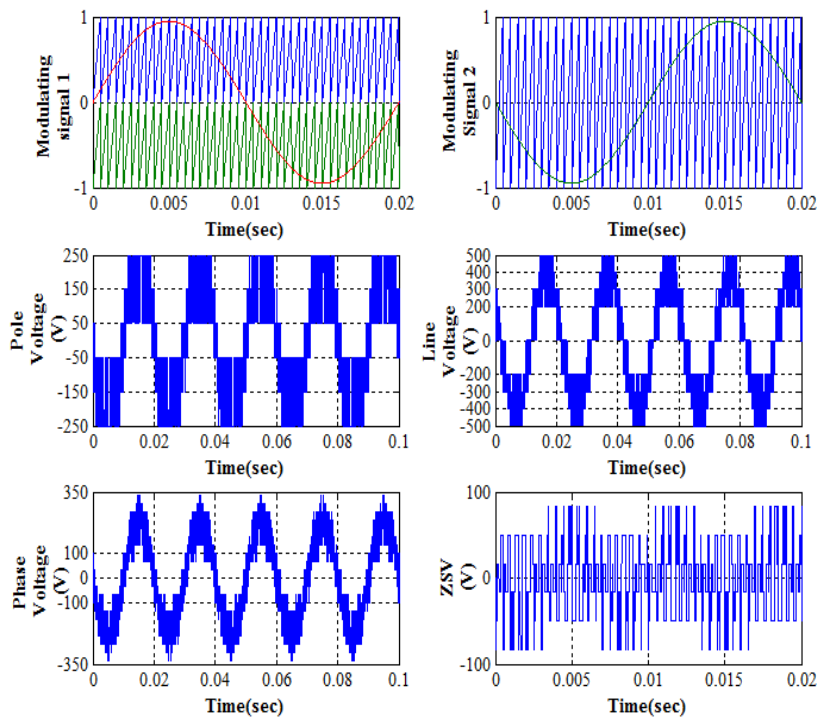

Fig. 11 Modulating signal, Pole voltage, Line voltage, phase voltage, ZSV for proposed 6-level inverter using SPWM

\section{Configuration-II}

\section{For 5-level multilevel inverter fed I.M drive using SPWM technique}

5-level multilevel inverter fed I.M drive is modeled and is simulated by employing Sinusoidal pulse width modulation (SPWM) control technique with Modulation index $=1$ (over modulation) and the reference and carrier wave comparison, pole voltage, output phase voltage, line voltage and ZSV for proposed 5 level inverter are shown in Fig. 12.
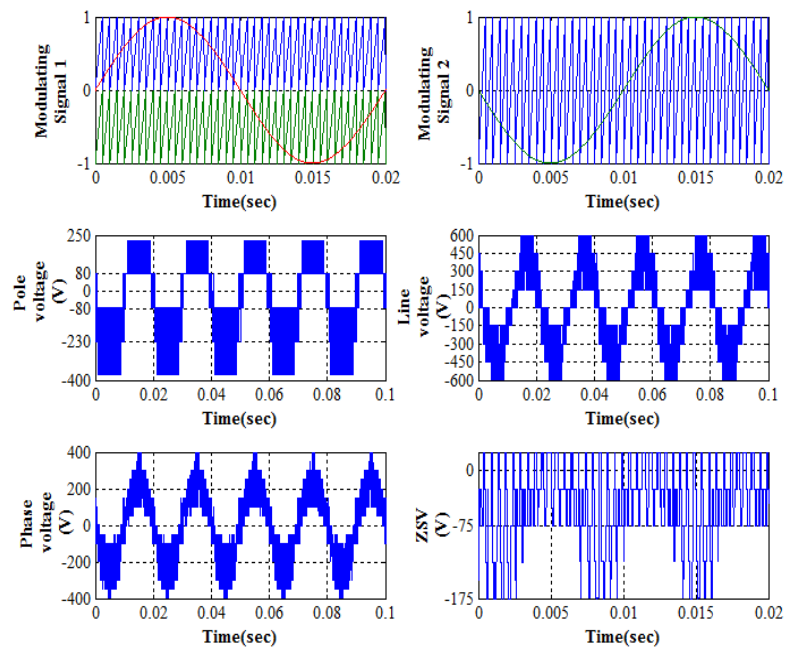

Fig. 12 Modulating signal, Pole voltage, Line voltage, phase voltage, ZSV for proposed 5-level inverter using SPWM

\section{For 6-level multilevel inverter fed I.M drive using SPWM technique}

6-level multilevel inverter fed I.M drive is modeled and is simulated by employing Sinusoidal pulse width modulation (SPWM) control technique with Modulation index $=1$ (over modulation) and the reference and carrier wave comparison, pole voltage, output phase voltage, line voltage and ZSV for proposed 6 level inverter are shown in Fig. 13. 

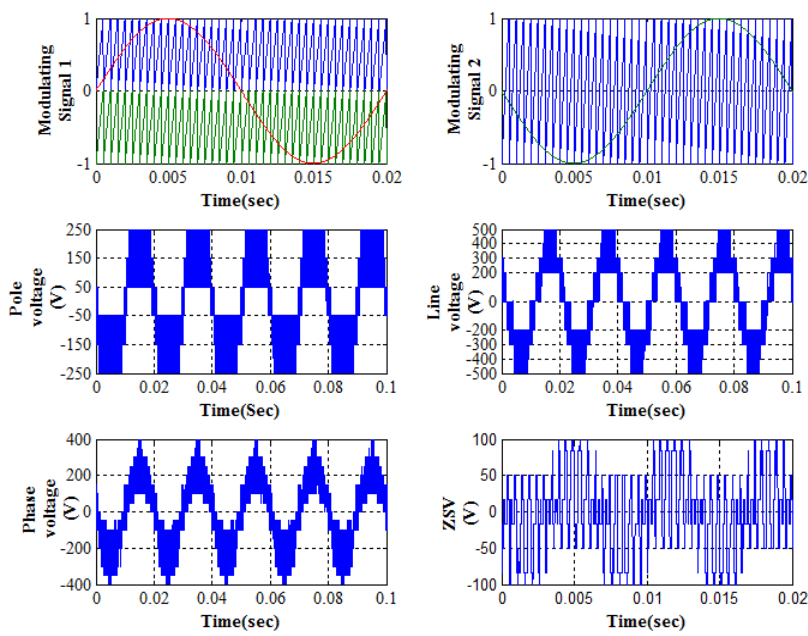

Fig. 13 Modulating signal, Pole voltage, Line voltage, phase voltage, ZSV for proposed 6-level inverter using SPWM

B) For Diode Clamped multilevel inverter (three level) fed I.M drive with THIPWM control

A 3-level multilevel inverter (i.e. DCMLI) fed induction motor drive is modeled and is simulated by employing Third Harmonic Injection pulse width modulation (THIPWM) control technique with Modulation index $=1$ (over modulation) and the reference and carrier wave comparison, output phase voltage, line voltage and ZSV of the inverter are shown in Fig. 14.
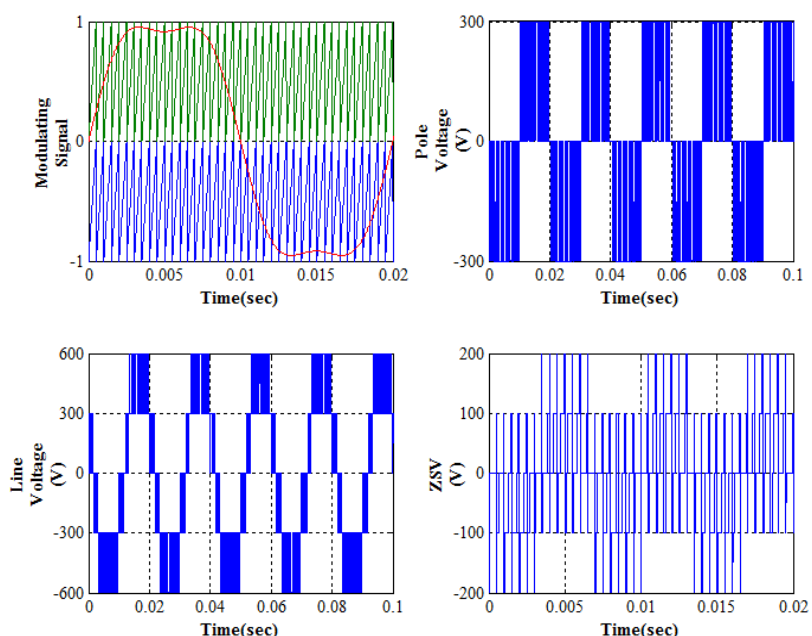

Fig. 14 Modulating signal, Pole voltage, Line voltage, ZSV for 3-level inverter Using THIPWM

The performance characteristics of Induction motor drive with THIPWM controlled 3-Level Inverter (DCMLI) i.e. Stator currents, Torque response, Speed response shown in the fig. The motor achieves steady state at $0.15 \mathrm{sec}$ and load is applied from 0.5 to $0.8 \mathrm{sec}$ and then reaches its steady state as shown in Fig. 15.
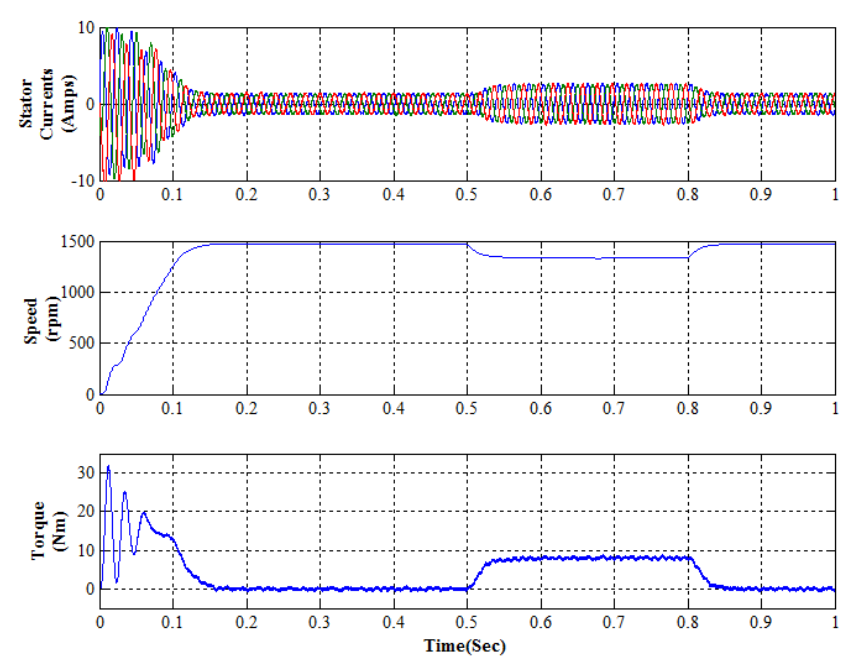

Fig. 15 Performance characteristics of IM drive with 3-level inverter Under load Condition

\section{For 3-level multilevel inverter fed I.M drive using THIPWM technique}

3-level multilevel inverter fed I.M drive is modeled and is simulated by employing Third Harmonic Injection pulse width modulation (THIPWM) control technique with Modulation index $=1$ (over modulation) and the reference and carrier wave comparison, pole voltage, output phase voltage, line voltage and ZSV for proposed 3 level inverter are shown in Fig. 16.
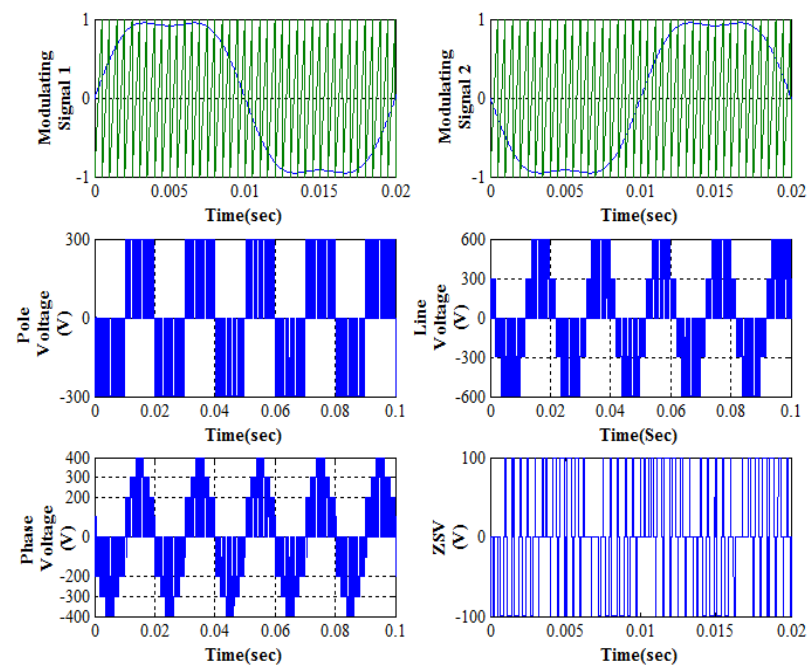

Fig. 16 Modulating signal, Pole voltage, Line voltage, phase voltage, ZSV for proposed 3-level inverter using THIPWM

\section{For 4-level multilevel inverter fed I.M drive using THIPWM technique}

4-level multilevel inverter fed I.M drive is modeled and is simulated by employing Third Harmonic Injection pulse width modulation (THIPWM) control technique with Modulation index $=1$ (over modulation) and the reference and carrier wave comparison, pole voltage, output phase voltage, line voltage and ZSV for proposed 4 level inverter are shown in Fig. 17. 

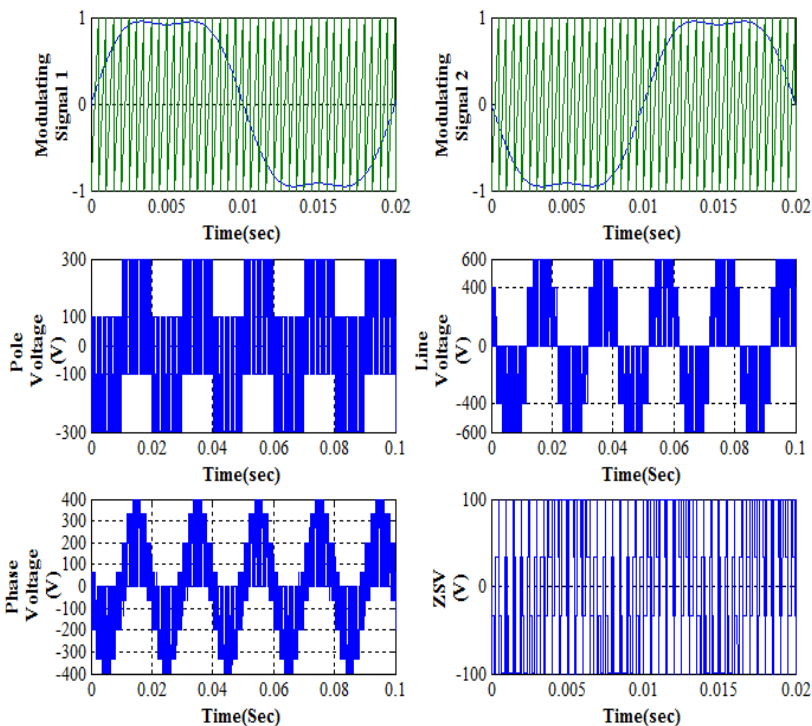

Fig. 17 Modulating signal, Pole voltage, Line voltage, phase voltage, ZSV for proposed 4-level inverter using THIPWM

\section{Configuration-I}

\section{For 5-level multilevel inverter fed I.M drive using THIPWM technique}

5-level multilevel inverter fed I.M drive is modeled and is simulated by employing Third Harmonic Injection pulse width modulation (THIPWM) control technique with Modulation index $=1$ (over modulation) and the reference and carrier wave comparison, pole voltage, output phase voltage, line voltage and ZSV for proposed 5 level inverter are shown in Fig. 18.
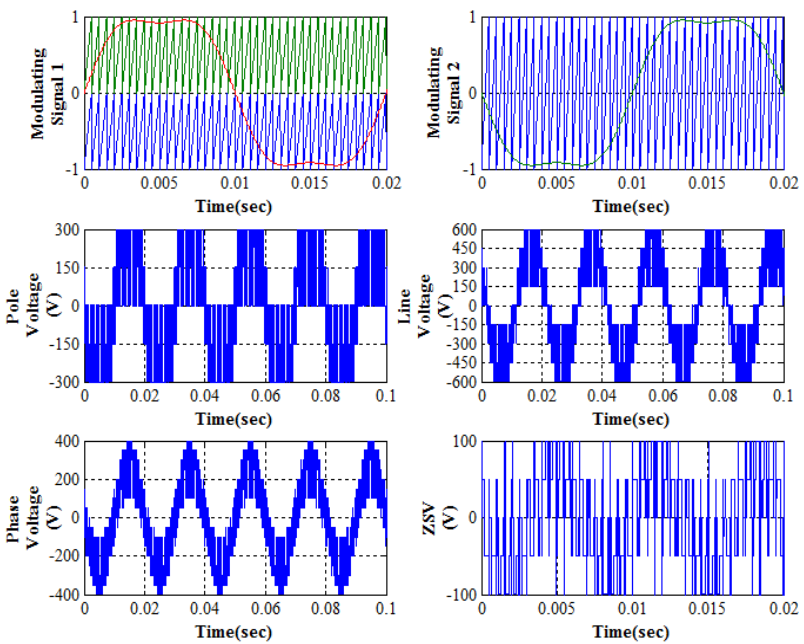

Fig. 18 Modulating signal, Pole voltage, Line voltage, phase voltage, ZSV for proposed 5-level inverter using THIPWM

\section{For 6-level multilevel inverter fed I.M drive using THIPWM technique}

6-level multilevel inverter fed I.M drive is modeled and is simulated by employing Third Harmonic Injection pulse width modulation (THIPWM) control technique with Modulation index $=1$ (over modulation) and the reference and carrier wave comparison, pole voltage, output phase voltage, line voltage and ZSV for proposed 6 level inverter are shown in Fig. 19.
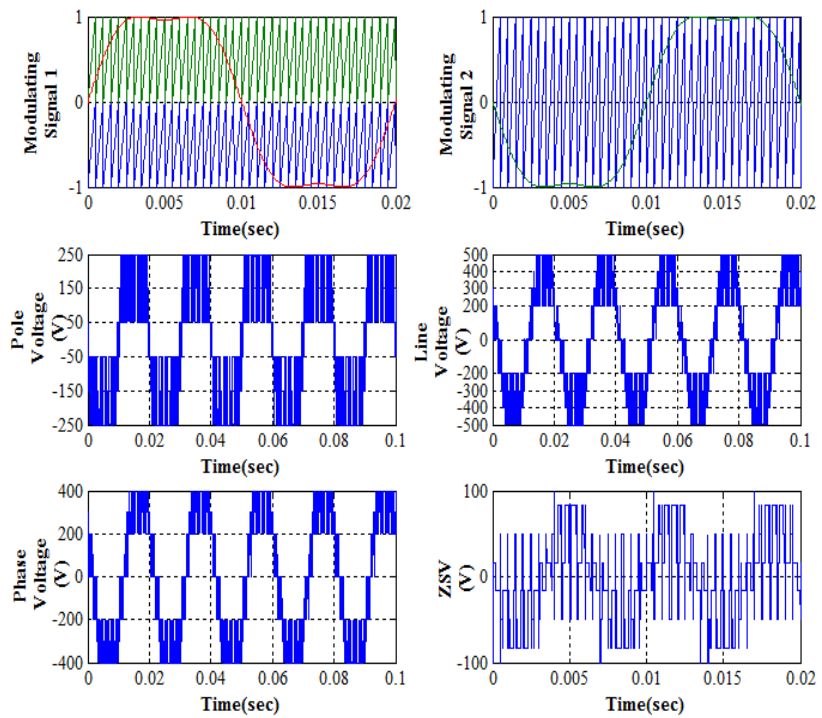

Fig. 19 Modulating signal, Pole voltage, Line voltage, phase voltage, ZSV for proposed 6-level inverter using THIPWM

\section{Configuration-II}

\section{For 5-level multilevel inverter fed I.M drive using THIPWM technique}

5-level multilevel inverter fed I.M drive is modeled and is simulated by employing Third Harmonic Injection pulse width modulation (THIPWM) control technique with Modulation index $=1$ (over modulation) and the reference and carrier wave comparison, pole voltage, output phase voltage, line voltage and ZSV for proposed 5 level inverter are shown in Fig. 20.
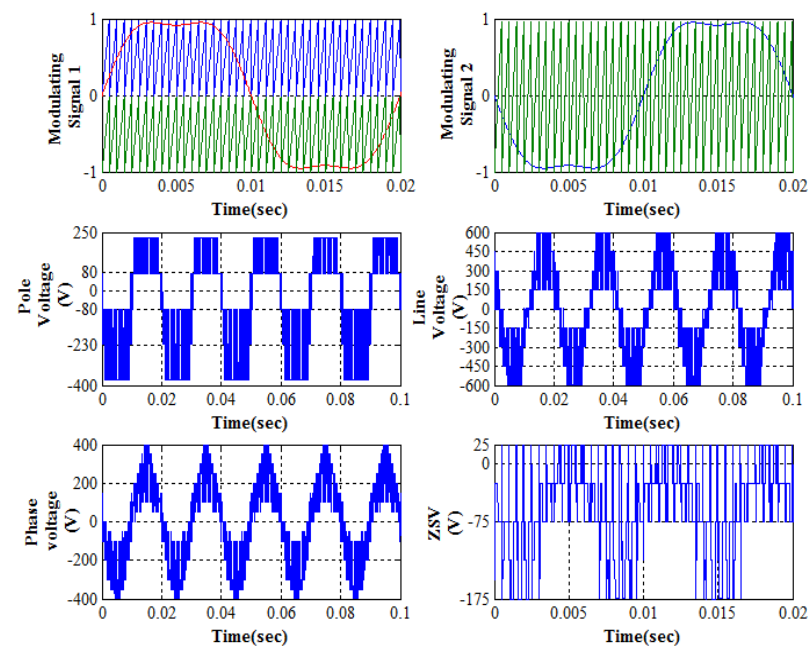

Fig. 20 Modulating signal, Pole voltage, Line voltage, phase voltage, ZSV for proposed 5-level inverter using THIPWM

\section{For 6-level multilevel inverter fed I.M drive using THIPWM technique}

6-level multilevel inverter fed I.M drive is modeled and is simulated by employing THIPWM control technique with Modulation index $=1$ (over modulation) and the reference and carrier wave comparison, pole voltage, output phase voltage, line voltage and ZSV for proposed 6 level inverter are shown in Fig. 21. 

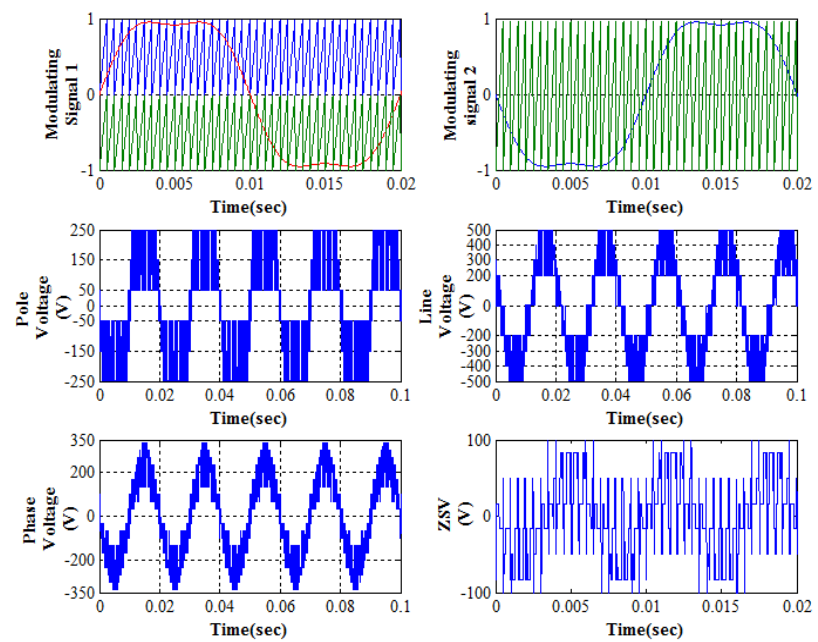

Fig. 21 Modulating signal, Pole voltage, Line voltage, phase voltage, ZSV for proposed6-level inverter using THIPWM

\section{C) THD Comparison}

Table 1 THD values of line voltages for SPWM Technique

\begin{tabular}{|c|c|c|c|}
\hline \multicolumn{2}{|c|}{ Inverter type } & $\begin{array}{c}\text { THD of } \\
\text { inverter } \\
\text { voltage }\left(\mathrm{V}_{\text {line }}\right) \\
\text { in under } \\
\text { modulation } \\
(\mathrm{M} . \mathrm{I}=0.75) \\
\text { region }(\%)\end{array}$ & $\begin{array}{l}\text { THD of inverter } \\
\text { Voltage } \\
\left(\mathrm{V}_{\text {line }} \mathrm{THD}\right) \text { in } \\
\text { over modulation } \\
(\mathrm{M} . \mathrm{I}=1) \text { region } \\
(\%)\end{array}$ \\
\hline \multicolumn{2}{|l|}{ 2-level } & 72.26 & 38.77 \\
\hline \multicolumn{2}{|c|}{ 3-level (DCMLI) } & 42.71 & 35 \\
\hline \multicolumn{2}{|l|}{ 3-level } & 72.98 & 39.17 \\
\hline \multicolumn{2}{|l|}{ 4-level } & 75.35 & 43.33 \\
\hline \multirow[t]{2}{*}{ Config-I } & 5-level & 60.37 & 36.14 \\
\hline & 6-level & 45.41 & 29.39 \\
\hline \multirow[t]{2}{*}{ Config-II } & 5-level & 51.77 & 32.57 \\
\hline & 6-level & 45.01 & 29.12 \\
\hline
\end{tabular}

Table 2 THD values of line voltages for THIPWM Technique

\begin{tabular}{|c|c|c|c|c|c|}
\hline \multirow{2}{*}{\multicolumn{2}{|c|}{ Inverter type }} & \multicolumn{2}{|c|}{$\begin{array}{l}\text { THD of inverter } \\
\text { voltage }\left(\mathrm{V}_{\text {line }}\right) \text { in } \\
\text { under modulation } \\
(\mathrm{M} . \mathrm{I}=0.75) \text { region } \\
(\%)\end{array}$} & \multicolumn{2}{|c|}{$\begin{array}{l}\text { THD of inverter } \\
\text { Voltage } \\
\left(\mathrm{V}_{\text {line }} \mathrm{THD}\right) \text { in } \\
\text { over modulation } \\
(\mathrm{M} . \mathrm{I}=1) \text { region } \\
(\%)\end{array}$} \\
\hline & & $\mathrm{K}=1 / 4$ & $\mathrm{~K}=1 / 6$ & $\mathrm{~K}=1 / 4$ & $\mathrm{~K}=1 / 6$ \\
\hline \multicolumn{2}{|l|}{ 2-level } & 69.85 & 68.36 & 36.14 & 32.57 \\
\hline \multicolumn{2}{|c|}{ 3-level (DCMLI) } & 40.83 & 40.09 & 27.42 & 26.8 \\
\hline \multicolumn{2}{|l|}{ 3-level } & 70.43 & 65.8 & 32.93 & 28.86 \\
\hline \multicolumn{2}{|l|}{ 4-level } & 71.68 & 67.81 & 35.93 & 32.63 \\
\hline \multirow[t]{2}{*}{ Config-I } & 5-level & 53.05 & 51.5 & 24.87 & 27.34 \\
\hline & 6-level & 41.45 & 40.55 & 22.78 & 20.62 \\
\hline \multirow{2}{*}{$\begin{array}{l}\text { Config- } \\
\text { II }\end{array}$} & 5-level & 46.13 & 44.83 & 25.17 & 22.83 \\
\hline & 6-level & 41.39 & 40.53 & 22.54 & 20.19 \\
\hline
\end{tabular}

\section{CONCLUSION}

In this paper, the implementation of inverter fed open winding I.M drive has been done by using different modulation techniques like SPWM and THIPWM. The Zero Sequence Voltage is also mitigated up to greater extent and there is gradual decrement in THD's using THIPWM because of maximum utilization of DC bus. This work can be extended by using advanced modulation techniques like SVPWM and Discontinuous PWM techniques.

\section{REFERENCES}

[1] GOPAKUMAR, K. - BAIJU, M. R. MOHAPATRA, K. K. - KANCHAN, R. S.: A Dual Two Level Inverter Scheme with Common Mode Voltage Elimination for an Induction Motor Drive, IEEE Transactions on Power Electronics, Vol. 19, No. 3, pp. 794-805, May 2004.

[2] RENDUSARA, D. A. - CENGELCI, E. - ENJETI, P. N. - STEFANOVIC, V. R. - GRAY, J. W.: Analysis of common mode voltage "Neutral shift" in medium voltage PWM adjustable speed drive (MV-ASD) systems, IEEE Transactions on Power Electronics, Vol. 15, No. 6, pp. 1124-1133, 2000.

[3] RODRIGUEZ, J. - PONTT, J. - CORREA, P. CORTÉS, P. - SILVA, C.: A new modulation method to reduce common-mode voltages in multilevel inverters, IEEE Transactions on Industrial Electronics, Vol. 51, No. 4, pp. 834-839, 2004.

[4] WANG, F.: Motor shaft voltages and bearing currents and their reduction in multilevel mediumvoltage PWM voltage source-inverter drive applications, IEEE Transactions on Industry Applications, Vol. 36, No. 5, pp. 1336-1341, 2000.

[5] WANG, F.: Sine-triangle versus space-vector modulation for three-level PWM voltage-source inverters, IEEE Transactions on Industry Applications, Vol. 38, No. 2, pp. 500-506, 2002.

[6] VENUGOPAL REDDY, B. - SOMASEKHAR, V. T.: A Decoupled SVPWM Technique for a Dual Inverter Four-level Open-end Winding Induction Motor Drive with Voltage Balancing of DC-link Capacitors, Conference proceedings, IEEE, 2010.

[7] DEEPTHI, J. - SAXENA, S. N.: Study of Variation of THD in a Diode Clamped Multilevel Inverter with respect to Modulation Index and Control Strategy, published in International Journal of Computer Applications ${ }^{\circledR}$ (IJCA), 2011.

[8] KUMAR, S. - AGARWAL, P.: Five-Level Inverter Fed Open-end Winding IM Drive, Conference, Proceedings IEEE, 2015.

[9] CHANDRA SEKHAR, K. - TULASI RAM DAS, G.: A Six- level SPWM Inverter for an Open-end Winding Induction Motor, Asian Power Electronics Journal, Vol. 1, No. 1, Aug. 2007.

[10] SUJOD, M. Z. - ERLICH, I.: Harmonics and common mode voltage in a DFIG with two level and three level NPC converter using standard PWM techniques, IEEE Transaction Industrial Electronics, pp. 1650-1655, Nov. 2013. 
Received August 28, 2016, accepted December 16, 2016

\section{BIOGRAPHIES}

Mahamkali Ranjit received B.Tech degree from Nalanda Institute of Engineering and Technology, Guntur, Andhra Pradesh in the year 2006. He received M.Tech degree in power electronics and Industrial drives from JNT University in the year 2011. Currently, he is with VNR Vignana Jyothi Institute of Engineering \& Technology, Hyderabad, as an Assistant Professor. His areas of interests are power electronic control of drives.

Sara Gowtami received B.Tech degree from Gokaraju Rangaraju Institute of Engineering and Technology,
Hyderabad, Telangana in the year 2012. She received M.Tech degree in power electronics from JNT University Hyderabad in the year 2016. Her areas of interests are multilevel inverters and drives.

Bommasani Ganesh Babu received B.Tech degree from Swarnadhra Institute of Engineering and Technology, Narsapuram, Andhra Pradesh in the year 2010. He received M.Tech degree in power electronics from JNT University Hyderabad in the year 2012. Currently, he is with VNR Vignana Jyothi Institute of Engineering \& Technology, Hyderabad, as an Assistant Professor. His areas of interests are multilevel inverters and renewable energy systems. 